\title{
Soil biochemical properties in brown and gray mine soils with and without hydroseeding
}

\author{
C. Thomas ${ }^{1}$, A. Sexstone ${ }^{1}$, and J. Skousen ${ }^{2}$ \\ ${ }^{1}$ USGS, Forest and Rangeland Ecological Research Center, Boise, ID 83706, USA \\ ${ }^{2}$ West Virginia University, Morgantown, WV 26506, USA \\ Correspondence to: J. Skousen (jskousen@wvu.edu)
}

Received: 22 May 2015 - Published in SOIL Discuss.: 23 June 2015

Revised: 24 August 2015 - Accepted: 3 September 2015 - Published: 16 September 2015

\begin{abstract}
Surface coal mining in the eastern USA disturbs hundreds of hectares of land every year and removes valuable and ecologically diverse eastern deciduous forests. Reclamation involves restoring the landscape to approximate original contour, replacing the topsoil, and revegetating the site with trees and herbaceous species to a designated post-mining land use. Re-establishing an ecosystem of ecological and economic value as well as restoring soil quality on disturbed sites are the goals of land reclamation, and microbial properties of mine soils can be indicators of restoration success. Reforestation plots were constructed in 2007 using weathered brown sandstone or unweathered gray sandstone as topsoil substitutes to evaluate tree growth and soil properties at Arch Coal's Birch River mine in West Virginia, USA. All plots were planted with 12 hardwood tree species and subplots were hydroseeded with a herbaceous seed mix and fertilizer. After 6 years, the average tree volume index was nearly 10 times greater for trees grown in brown $\left(3853 \mathrm{~cm}^{3}\right)$ compared to gray mine soils $\left(407 \mathrm{~cm}^{3}\right)$. Average $\mathrm{pH}$ of brown mine soils increased from 4.7 to 5.0, while gray mine soils declined from 7.9 to 7.0. Hydroseeding doubled tree volume index and ground cover on both mine soils. Hydroseeding doubled microbial biomass carbon (MBC) on brown mine soils ( $8.7 \mathrm{vs.} 17.5 \mathrm{mg} \mathrm{kg}^{-1}$ ), but showed no effect on gray mine soils (13.3 vs. $\left.12.8 \mathrm{mg} \mathrm{kg}^{-1}\right)$. Hydroseeding also increased the ratio of $\mathrm{MBC}$ to soil organic $\mathrm{C}$ in both soils and more than tripled the ratio for potentially mineralizable nitrogen (PMN) to total N. Brown mine soils were a better growth medium than gray mine soils and hydroseeding was an important component of reclamation due to improved biochemical properties and microbial activity in mine soils.
\end{abstract}

\section{Introduction}

Surface mining in the eastern USA disturbs hundreds of hectares of land by removing ecologically diverse eastern deciduous forests, resulting in the disruption and degradation of underlying soil resources. In order to restore soil function and stability to these ecosystems (Brevik et al., 2015), a sufficient medium for plant growth must be re-established through reclamation. The most ideal material to place on the surface is the pre-existing soil material (Skousen et al., 2011; Zipper et al., 2013). Currently, brown and gray sandstones often are employed as substitutes for topsoil (Emerson et al., 2009; Skousen et al., 2011). The brown sandstone substitute materials have a $\mathrm{pH}$ from 4.5 to 5.5 compared to the gray sandstone materials with a $\mathrm{pH}$ of 7.5 to 8.0 (Wilson-Kokes et al., 2013a, b). These low $\mathrm{pH}$ conditions in brown mine soil are more conducive to tree growth, while the higher $\mathrm{pH}$ of gray mine soils is better for many seeded grasses (Zipper et al., 2013). Both mine soils tend to contain high levels of rock fragments, which translates into poor water-holding capacity and poor nutrient relations in these topsoil substitutes (Haering et al., 2004). However, the temporal dynamics of the physical, chemical, and biochemical properties of topsoil substitutes following reclamation are not sufficiently understood.

Microorganisms are known to play an important role in reestablishing soil organic matter content and restoring ecosystem services following surface mining or other land disturbances (Anderson et al., 2008; Machulla et al., 2005; Haney 
et al., 2008; Ingram et al., 2005; Zipper et al., 2011). However, their biochemical activities can be slow to re-establish (Chodak, 2009) and may take several decades to reach stable conditions normally found in native soils (Chatterjee et al., 2009; Insam and Domsch, 1988). Soil carbon amendments stimulate microbiological activity (Bendfeldt et al., 2001; Elkins et al., 1984; Lindemann et al., 1984), as can the establishment of herbaceous plants using the additions of fertilizers and lime (Chaudhuri et al., 2015). However, as easily decomposable organic matter is rapidly consumed, an overall decline of microbial activity results if no further additions of external nutrients and organic matter are applied because a reservoir of soil organic matter is lacking in newly created mine soils (Stephens et al., 2001; Stroo and Jencks, 1982). Compaction of soil materials and planting of competitive forage species have been shown to arrest the re-colonization of native hardwood tree species and slow natural succession on these reclaimed sites (Franklin et al., 2012; Groninger et al., 2007), which also tends to diminish microbial diversity and activity. Hydroseeding to introduce lime, fertilizer, mulch, and seed is already a common practice in surface mine reclamation, and using lower rates of seed, fertilizer and lime, as well as using different herbaceous species, aids the development of forests on these sites (Franklin et al., 2012; Showalter et al., 2010). Hydroseeding a non-competitive, tree-compatible herbaceous forage mix can still meet the requirements for soil stabilization and conditioning, and may also be useful for re-establishing microbial communities that aid in nutrient cycling (Zipper et al., 2011). The objective of this study was to determine tree growth and soil properties including microbial biomass carbon (MBC) and potentially mineralizable nitrogen (PMN) in brown and gray mine soils and to determine the influence of a hydroseed treatment on these properties.

\section{Materials and methods}

Arch Coal's Birch River Operation is located near Cowen in Webster County, West Virginia, approximately $100 \mathrm{~km}$ northeast of Charleston $\left(38^{\circ} 25^{\prime} 31^{\prime \prime} \mathrm{N} 80^{\circ} 36^{\prime} 39^{\prime \prime} \mathrm{W}\right)$. Coal from the Kittanning, Clarion, Stockton and Coalburg seams was mined at the site. Overburden was moved from above the seams by shovels, front-end loaders, bulldozers, trucks, and dragline. The vegetative cover on pre-mining land was a mixed hardwood forest. Gilpin and Gilpin-Dekalb series (Typic Hapludults) with soil textures of silt loam and sandy loam and containing 15 to $25 \%$ rock fragments were the preexisting soil types on the moderate to steep slopes of the region (Delp, 1998).

In January 2007, a 4.9 ha plot was created using two types of sandstone overburden. Half of the area was constructed with weathered brown sandstone, the other half with unweathered gray sandstone. Overburden materials were enddumped into conjoining piles that were approximately $1.5 \mathrm{~m}$ deep throughout the plot. To limit compaction, a bulldozer made only one pass over the piles to strike off the tops, resulting in approximately $1.2 \mathrm{~m}$ depth of rough-graded material. In spring 2007, 12 species of tree seedlings were purchased from the West Virginia State Tree Nursery and planted on $2.4 \mathrm{~m}$ centers by Williams Forestry, a professional tree planting company, at a stocking rate of 1680 trees per ha (Table 1). In the fall of 2008, both ends of the plot were hydroseeded with a seed mix of compatible herbaceous species at a rate of $36 \mathrm{~kg} \mathrm{ha}^{-1}$ (Table 2), and fertilized at a rate of $336 \mathrm{~kg} \mathrm{ha}^{-1}$ of $10-20-10\left(\mathrm{~N}-\mathrm{P}_{2} \mathrm{O}_{5}-\mathrm{K}_{2} \mathrm{O}\right)$.

\section{Sampling and analyses}

Survival and growth of trees as well as soil physical and chemical properties was measured from 2007 to 2012 as reported in Wilson-Kokes et al. (2013b). Tree growth was assessed by measuring height and stem diameter at $2.5 \mathrm{~cm}$ above ground, and a tree volume index was calculated as height $\times$ diameter ${ }^{2}$. Percent ground cover from herbaceous plants, litter, and trees were also determined and reported as above.

Soil samples were collected from the top $15 \mathrm{~cm}$ at four randomly selected points along transects within each treatment combination in July of 2007 to 2012. No surface organic layer formed at this site as either a litter layer or as an A horizon during the course of this study. Field soils were air dried and sieved through a $2 \mathrm{~mm}$ sieve to separate the fine soil fraction $(<2 \mathrm{~mm})$ from the coarse or rock fraction $(\geq 2 \mathrm{~mm})$. The fine soil fraction was used for all chemical and biochemical analysis.

Soil $\mathrm{pH}$ was measured in a $1: 2$ mixture of $5 \mathrm{~g}$ of soil and $10 \mathrm{~mL}$ of distilled deionized water (DDI) water with a Fisher Scientific Accumet pH meter model 915 (Thermo Fisher Scientific Inc., Pittsburgh, PA). Electrical conductivity (EC) was measured using a 1:2 mixture on a Mettler Toledo S230 EC meter (Mettler-Toledo International Inc., Columbus, $\mathrm{OH}$ ). Nutrients were determined using a Mehlich 1 extraction solution $\left(0.05 \mathrm{M} \mathrm{HCl}\right.$ and $\left.0.025 \mathrm{M} \mathrm{H}_{2} \mathrm{SO}_{4}\right)$, but are not reported here, and results can be found in Wilson-Kokes et al. (2013b).

Biochemical measurements were made only on soil samples taken in 2012. Total carbon (TC) and nitrogen (TN) were measured with a Leco TruSpec CHN elemental analyzer (LECO Corp., St Joseph, MI). A $0.10 \mathrm{~g}$ sample of air-dried soil was weighed into foil cups and combusted at $950^{\circ} \mathrm{C}$. Carbon fractions were also determined. Carbonate $\mathrm{C}$ was determined in soils by reaction with a $1 \mathrm{M} \mathrm{HCl}$ solution as described by Ussiri and Lal (2008). For soil organic C, $1 \mathrm{~g}$ of soil was weighed into ceramic crucibles and thermally oxidized at $340^{\circ} \mathrm{C}$ for $3 \mathrm{~h}$, after which samples were reweighed. Coal $\mathrm{C}$ was calculated as the difference between TC minus carbonate $\mathrm{C}$ and soil organic $\mathrm{C}$.

Microbial biomass carbon (MBC) of the soil was determined using the chloroform fumigation extraction method 
Table 1. Species and number of trees planted in 2007 at the Arch-Birch River mine in Webster County, West Virginia.

\begin{tabular}{lrr}
\hline Species & Number of trees planted & Percent of trees planted \\
\hline Black cherry (Prunus serotina Ehrh.) & 880 & 11 \\
Northern red oak (Quercus rubra L.) & 880 & 11 \\
Sugar maple (Acer saccharum Marsh.) & 880 & 11 \\
White ash (Fraxinus americana L.) & 880 & 11 \\
White oak (Quercus alba L.) & 880 & 11 \\
Black locust (Robinia psuedoacacia L.) & 800 & 10 \\
Pitch X loblolly pine (Pinus X rigitaeda) & 800 & 10 \\
Tulip poplar (Liriodendron tulipifera L.) & 640 & 8 \\
Sycamore (Platanus occidentalis L.) & 480 & 6 \\
Eastern white pine (Pinus strobus L.) & 400 & 5 \\
Dogwood (Cornus alternifolia L.) & 320 & 4 \\
Eastern redbud (Cercis canadensis L.) & 320 & 4 \\
\hline Total & 8160 & 100 \\
\hline
\end{tabular}

Table 2. Species and rate of application of ground cover hydroseeded in 2008 at the Arch-Birch River mine in Webster County, West Virginia.

\begin{tabular}{lr}
\hline Species & $\begin{array}{r}\text { Rate } \\
\mathrm{kg} \mathrm{ha}^{-1}\end{array}$ \\
\hline Birdsfoot trefoil (Lotus corniculatus L.) & 11.2 \\
Kobe lespedeza (Kummerowia striata Maxim.) & 5.6 \\
Ladino clover (Trifolium repens L.) & 3.3 \\
Orchard grass (Dactylis glomerata L.) & 5.6 \\
Perennial ryegrass (Lolium perenne L.) & 5.6 \\
Redtop (Agrostis gigantea Roth) & 2.2 \\
Weeping lovegrass (Eragrostis curvula Schra.) & 2.2 \\
\hline Total & 35.7 \\
\hline
\end{tabular}

from Brookes and Joergensen (2006). Two triplicate sets of $10 \mathrm{~g}$ (dry weight) samples of field moist soil were weighed into $125 \mathrm{~mL}$ glass serum bottles. One set of triplicate samples was designated as a control and did not undergo chloroform fumigation. Fumigated samples were exposed to $2 \mathrm{~mL}$ of amylene-stabilized chloroform. Air-tight rubber stoppers were used to cap bottles prior to creation of a vacuum by pulling air from each bottle, followed by incubation for $24 \mathrm{~h}$ in the dark prior to extraction. Both fumigated and control samples were extracted with $25 \mathrm{~mL}$ of $0.5 \mathrm{M} \mathrm{K}_{2} \mathrm{SO}_{4}$ on a reciprocating shaker for $60 \mathrm{~min}$. Samples were vacuum filtered through $0.45 \mu \mathrm{m}$ Millipore filters yielding a soil-free extract that was frozen until analyzed using a Sievers 5310C Total Organic Carbon Analyzer (GE Analytical Instruments, Boulder, CO). MBC was calculated as the difference between the control and fumigated samples divided by an extraction efficiency factor of 0.35 . Potentially mineralizable nitrogen was determined using the anaerobic incubation method (Canali and Benedetti, 2006). Non-incubated control triplicate samples were created by weighing $16 \mathrm{~g}$ (dry weight) of field moist soil and adding $40 \mathrm{~mL}$ of distilled deionized water into $250 \mathrm{~mL}$ glass Erlenmeyer flasks. Soil was extracted with $40 \mathrm{~mL}$ of $2 \mathrm{M} \mathrm{KCl}$ for $60 \mathrm{~min}$ on a reciprocating shaker. Supernatant was filtered through $0.45 \mu \mathrm{m}$ Millipore filters and frozen until further analysis. Anaerobically incubated triplicate samples were created by weighing $16 \mathrm{~g}$ (dry weight) of field moist soil into $50 \mathrm{~mL}$ polypropylene centrifuge tubes. Soil was suspended in $40 \mathrm{~mL}$ of distilled deionized water, and the tubes stoppered and then incubated at $40{ }^{\circ} \mathrm{C}$ for 7 days. Every $24 \mathrm{~h}$ during the incubation period, soil was resuspended in solution. After the incubation period, the soilwater solution was transferred to a $250 \mathrm{~mL}$ glass Erlenmeyer flask. Centrifuge tubes were rinsed four times with $2 \mathrm{M} \mathrm{KCl}$ into the same Erlenmeyer flasks. Samples were extracted, filtered and stored in a similar manner to control samples. A colorimetric method described by Mulvaney (1996) was used to determine the amount of nitrogen in the form of ammonium $\left(\mathrm{NH}_{4}^{+}\right)$present in the filtered supernatants. The difference between non-incubated and incubated samples was calculated and recorded as the PMN. Total C, C fractions (soil organic $\mathrm{C}$, carbonate $\mathrm{C}$, and coal C), total $\mathrm{N}, \mathrm{MBC}$, and PMN were analyzed by one-way analysis of variance by mine soil type and hydroseed application and combinations. Treatment means when found significantly different by analysis of variance were separated by Tukey's honest significant difference test at the $p \leq 0.05$ level. The $\mathrm{R}$ language and environment for statistical computing was used for all analyses (R Development Core Team, 2011).

\section{Results and discussion}

Detailed annual results of tree survival and growth on the site have been previously reported (Wilson-Kokes et al., 2013b). In brief, these data showed that after six growing seasons (2007-2012), tree survival was significantly higher in brown mine soil treatments compared to gray mine soils 
Table 3. Mean tree volume index ${ }^{1}$ for 2008-2012 growing seasons in four soil treatments at the Arch-Birch River mine in Webster County, WV (Wilson-Kokes et al., 2013b).

\begin{tabular}{crrrr}
\hline & \multicolumn{4}{c}{ Treatments } \\
\cline { 2 - 5 } Year & Brown & $\begin{array}{c}\text { Brown- } \\
\text { hydroseed }\end{array}$ & Gray & $\begin{array}{r}\text { Gray- } \\
\text { hydroseed }\end{array}$ \\
\hline \multicolumn{5}{c}{$\mathrm{cm}^{3}$} \\
\hline 2008 & $43^{\mathrm{a}, 2}$ & $50^{\mathrm{a}}$ & $27^{\mathrm{a}}$ & $17^{\mathrm{a}}$ \\
2009 & $218^{\mathrm{a}}$ & $293^{\mathrm{a}}$ & $30^{\mathrm{b}}$ & $40^{\mathrm{b}}$ \\
2010 & $582^{\mathrm{a}, \mathrm{b}}$ & $712^{\mathrm{a}}$ & $72^{\mathrm{c}}$ & $229^{\mathrm{b}, \mathrm{c}}$ \\
2011 & $2086^{\mathrm{a}}$ & $1687^{\mathrm{a}}$ & $248^{\mathrm{b}}$ & $163^{\mathrm{b}}$ \\
2012 & $3316^{\mathrm{a}, \mathrm{b}}$ & $6243^{\mathrm{a}}$ & $818^{\mathrm{c}}$ & $1663^{\mathrm{b}, \mathrm{c}}$ \\
\hline
\end{tabular}

${ }^{1}$ Tree volume index determined by tree height and diameter ${ }^{2}$ (measured at $5 \mathrm{~cm}$ above ground).

2 Means for each volume within rows (years) with the same letter are not significantly different at $P<0.05$.

( 83 vs. $72 \%$; data not shown). Average tree volume index (height $\times$ diameter $^{2}$ ) also was significantly higher for trees grown in brown mine soils compared to gray mine soils after 6 years and hydroseed treatment doubled the tree volume index on both mine soils (Table 3).

Traditionally, aggressive herbaceous vegetation is thought to out-compete tree seedlings for nutrients, water, and solar energy when seeded at high densities (Fields-Johnson et al., 2012). However, when tree-compatible species such as birdsfoot trefoil (Lotus corniculatus L.) and ladino clover (Trifolium repens L.) are seeded, they can benefit tree seedling growth by reducing evapotranspiration, shading the soil surface, and increasing the soil water-holding capacity through adding organic matter to the soil via root decay (Franklin et al., 2012). In our study, tree survival in hydroseed areas was $82 \%$, which was not significantly different from survival in non-hydroseed areas at $76 \%$ (Thomas, 2012). Hydroseeding by mine soil type resulted in $78 \%$ survival and $6243 \mathrm{~cm}^{3}$ tree volume index on brown and $100 \%$ survival and $1663 \mathrm{~cm}^{3}$ tree volume index on gray (Table 3 ).

Treatments with hydroseeding initially had significantly higher herbaceous cover with $30 \%$ for brown and $22 \%$ for gray than those treatments without hydroseeding (3 to $12 \%$, Table 4). Gray mine soils alone had the lowest average total cover at $11 \%$, while all other treatment combinations averaged 27 to $39 \%$ total cover (Table 4). Perennial ryegrass (Lolium perenne L.) and orchardgrass (Dactylis glomeratus L.) were the predominant herbaceous species found and accounted for more than $75 \%$ of the total herbaceous cover. Legumes in the seeding mix did not establish well and only made up a small part of the herbaceous cover. Hydroseeding was found to be an important component of reclamation because it significantly increased the amount of total cover on hydroseed areas and, as already noted, doubled the tree vol-
Table 4. Mean ground cover on four soil treatments in 2012 at the Arch-Birch River mine in Webster County, WV (Wilson-Kokes et al., 2013b).

\begin{tabular}{lrrrr}
\hline & \multicolumn{4}{c}{ Treatments } \\
\cline { 2 - 5 } Cover & Brown & $\begin{array}{c}\text { Brown- } \\
\text { hydroseed }\end{array}$ & Gray & $\begin{array}{r}\text { Gray- } \\
\text { hydroseed }\end{array}$ \\
\hline Herbaceous & $12^{\mathrm{c}, *}$ & $30^{\mathrm{a}}$ & $3^{\mathrm{d}}$ & $22^{\mathrm{b}}$ \\
Tree & $15^{\mathrm{a}}$ & $9^{\mathrm{a}}$ & $8^{\mathrm{a}}$ & $9^{\mathrm{a}}$ \\
Total cover & $27^{\mathrm{b}}$ & $39^{\mathrm{a}}$ & $11^{\mathrm{c}}$ & $29^{\mathrm{b}}$ \\
Bare/rock & $73^{\mathrm{b}}$ & $61^{\mathrm{c}}$ & $89^{\mathrm{a}}$ & $69^{\mathrm{b}}$ \\
\hline
\end{tabular}

* Means for each treatment combination within rows with the same letter are not significantly different at $P<0.05$.

ume index of trees growing on hydroseed areas compared to non-hydroseed areas.

Birch River mine soils exhibited similar differences in physical and chemical properties as those observed in other studies of brown and gray sandstone mine soils (Angel et al., 2008; Emerson et al., 2009). The $\mathrm{pH}$ values for brown mine soils had the lowest mean values of all treatment combinations, 5.0 for brown and 5.5 for brown-hydroseed (Table 5). Gray mine soils ranged in $\mathrm{pH}$ from 7.0 to 7.9. The mean $\mathrm{pH}$ ranges for brown mine soils in this study fell within the typical range for mine soils created from weathered sandstones (pH 4.5 to 5.5 ), while the gray mine soils were slightly below to within the typical range for unweathered sandstones (pH 7.5 to 8.0) (Haering et al., 2004; Wilson-Kokes et al., 2013a; Zipper et al., 2013). Compared to initial values measured in 2008, EC values measured in 2012 had not declined substantially, with average ECs ranging from 0.06 to $0.12 \mathrm{dS} \mathrm{m}^{-1}$. All EC values were $<0.5 \mathrm{dS} \mathrm{m}^{-1}$, well below the level at which sensitive species such as sugar maple and white pine experience reduced tree growth and survival. Values of greater than $2 \mathrm{dS} \mathrm{m}^{-1}$ have been shown to have detrimental effects on plant growth (McFee et al., 1981; Whiting et al., 2010). Hydroseeding had little effect on soil $\mathrm{pH}$ and EC (Table 5).

Percent fines were significantly greater for brown (47 to $58 \%$ ) vs. gray ( 25 to $42 \%$ ) mine soils, another common result in similar studies. Miller et al. (2010) found that gray sandstone rocks exhibited a higher durability in a slakedurability test and were highly resistant to weathering during the freeze-thaw test. Zipper et al. (2011) reported that mine soils derived from gray sandstone would continue to have higher coarse fragments and lower percent fines than brown sandstone mine soils as they age because of resistance to degradation. High percentages of coarse fragments reduce water-holding capacities, which can negatively influence a site's productivity and tree growth (Rodrigue and Burger, 2004). 
Table 5. 2008 and 2012 soil properties of samples from four soil treatments at the Arch-Birch River mine in Webster County, WV (Wilson-Kokes et al., 2013b).

\begin{tabular}{lrrrr}
\hline & \multicolumn{4}{c}{ Treatments } \\
\cline { 2 - 5 } Property & Brown & $\begin{array}{c}\text { Brown- } \\
\text { hydroseed }\end{array}$ & Gray & $\begin{array}{r}\text { Gray- } \\
\text { hydroseed }\end{array}$ \\
\hline $\mathrm{pH}$ & \multicolumn{5}{c}{ su } \\
\hline 2008 & $4.7^{\mathrm{b}, 1}$ & $4.8^{\mathrm{b}}$ & $7.9^{\mathrm{a}}$ & $7.4^{\mathrm{a}}$ \\
2012 & $5.0^{\mathrm{b}}$ & $5.5^{\mathrm{b}}$ & $7.0^{\mathrm{a}}$ & $7.7^{\mathrm{a}}$ \\
\hline EC & \multicolumn{5}{c}{$\mathrm{dS} \mathrm{m} \mathrm{m}^{-1}$} \\
\hline 2008 & $0.12^{\mathrm{a}}$ & $0.06^{\mathrm{b}}$ & $0.12^{\mathrm{a}}$ & $0.12^{\mathrm{a}}$ \\
2012 & $0.06^{\mathrm{b}}$ & $0.07^{\mathrm{b}}$ & $0.11^{\mathrm{a}}$ & $0.09^{\mathrm{a}, \mathrm{b}}$ \\
\hline Fines & \multicolumn{5}{c}{$\%$} \\
\hline 2008 & $58^{\mathrm{a}}$ & $47^{\mathrm{b}}$ & $42^{\mathrm{b}}$ & $34^{\mathrm{c}}$ \\
2012 & $63^{\mathrm{a}}$ & $55^{\mathrm{a}, \mathrm{b}}$ & $40^{\mathrm{b}}$ & $25^{\mathrm{c}}$ \\
\hline
\end{tabular}

${ }^{1}$ Means for each treatment combination within rows with the same letter are not significantly different at $P<0.05$.

${ }^{2}$ Material that passed a $2 \mathrm{~mm}$ sieve.

Brown mine soils had significantly greater total $\mathrm{C}$ and soil organic $\mathrm{C}$ than gray mine soils, while carbonate $\mathrm{C}$ and coal $\mathrm{C}$ were similar among mine soil types (Table 6). Total $\mathrm{N}$ was not significantly different among treatments and ranged from 68 to $104 \mathrm{mg} \mathrm{kg}^{-1}$ (Table 6), and coal $\mathrm{N}$ was about $5 \%$ of the total N (data not shown). Waschkies and Hüttl (1999) found heterotrophic microflora and fauna were capable of utilizing coal $\mathrm{C}$ in mine soil materials, but the levels of $\mathrm{N}$ in coal in this study were not sufficient for utilization by plants or microbes (Thomas, 2012).

Hydroseed application had a significant effect on MBC in brown mine soils and PMN in both mine soils (Table 7). MBC in hydroseed plots on brown mine soils had a mass of $17.5 \mathrm{mg} \mathrm{kg}^{-1}$ compared to $8.7 \mathrm{mg} \mathrm{kg}^{-1}$ in nonhydroseed plots. Mean PMN in hydroseed treatments was almost triple $\left(0.81 \mathrm{mg} \mathrm{kg}^{-1}\right)$ that in non-hydroseed treatments $\left(0.35 \mathrm{mg} \mathrm{kg}^{-1}\right)$. MBC on our gray mine soils was similar, varying between 12.8 and $13.3 \mathrm{mg} \mathrm{kg}^{-1}$. However, PMN on gray hydroseed plots was more than 3 times greater at $0.92 \mathrm{mg} \mathrm{kg}^{-1}$ compared to non-hydroseed plots having $0.22 \mathrm{mg} \mathrm{kg}^{-1}$. In a chronosequence mine soil study, Stephens et al. (2001) found MBC to vary between 266 and $3351 \mathrm{mg} \mathrm{kg}^{-1}$, which was 1 to 3 orders of magnitude greater than MBC in our study. The Stephens et al. (2001) study had mine soils varying from 2 to 30 years old, and they were comprised of replaced native soils rather than crushed sandstone materials. A similar 2 orders of magnitude difference was found for PMN between their study and our study. On the other hand, Littlefield et al. (2013) found small amounts of MBC in reforested mine soils from 1 to 8 years old, which varied from 9 to $57 \mathrm{mg} \mathrm{kg}^{-1}$. Their values were much closer
Table 6. Carbon and nitrogen fractions in mine soil samples after six growing seasons at the Birch River Operation in Webster County, WV.

\begin{tabular}{lrrrr}
\hline & \multicolumn{4}{c}{ Treatments } \\
\cline { 2 - 5 } Property & Brown & $\begin{array}{c}\text { Brown- } \\
\text { hydroseed }\end{array}$ & Gray & $\begin{array}{r}\text { Gray- } \\
\text { hydroseed }\end{array}$ \\
\hline \multicolumn{5}{c}{$\mathrm{mg} \mathrm{kg}^{-1}$} \\
\hline Total C & $1880^{\mathrm{a}, *}$ & $1760^{\mathrm{a}}$ & $1412^{\mathrm{b}}$ & $1463^{\mathrm{b}}$ \\
Soil organic C & $806^{\mathrm{a}}$ & $964^{\mathrm{a}}$ & $659^{\mathrm{b}}$ & $507^{\mathrm{b}}$ \\
Carbonate C & $346^{\mathrm{a}}$ & $185^{\mathrm{a}}$ & $240^{\mathrm{a}}$ & $323^{\mathrm{a}}$ \\
Coal C & $728^{\mathrm{a}}$ & $611^{\mathrm{a}, \mathrm{b}}$ & $513^{\mathrm{b}}$ & $633^{\mathrm{a}}, \mathrm{b}$ \\
Total N & $104^{\mathrm{a}}$ & $75^{\mathrm{a}}$ & $96^{\mathrm{a}}$ & $68^{\mathrm{a}}$ \\
\hline * Means for each treatment combination within rows with the same letter are not \\
significantly different at $P<0.05$.
\end{tabular}

Table 7. Biochemical properties and ratios for mine soils after six growing seasons at the Birch River Operation in Webster County, WV.

\begin{tabular}{lcccc}
\hline & \multicolumn{4}{c}{ Treatments } \\
\cline { 2 - 5 } Property & Brown $\begin{array}{c}\text { Brown- Gray } \\
\text { hydroseed }\end{array}$ & $\begin{array}{c}\text { Gray- } \\
\text { hydroseed }\end{array}$ \\
\hline \multicolumn{5}{c}{$\mathrm{mg} \mathrm{kg}^{-1}$} \\
\hline MBC & $8.7^{\mathrm{c}, 2}$ & $17.5^{\mathrm{a}}$ & $13.3^{\mathrm{b}}$ & $12.8^{\mathrm{b}}$ \\
PMN & $0.35^{\mathrm{b}}$ & $0.81^{\mathrm{a}}$ & $0.22^{\mathrm{b}}$ & $0.92^{\mathrm{a}}$ \\
\hline \multicolumn{5}{c}{$\%$} \\
MBC: TC & $0.46^{\mathrm{b}}$ & $0.99^{\mathrm{a}}$ & $0.94^{\mathrm{a}}$ & $0.87^{\mathrm{a}}$ \\
MBC : OC & $1.08^{\mathrm{c}}$ & $1.82^{\mathrm{b}}$ & $2.02^{\mathrm{b}}$ & $2.52^{\mathrm{a}}$ \\
PMN : TN & $0.34^{\mathrm{b}}$ & $1.08^{\mathrm{a}}$ & $0.23^{\mathrm{b}}$ & $1.35^{\mathrm{a}}$ \\
\hline
\end{tabular}

${ }^{1} \mathrm{MBC}$ - microbial biomass carbon; PMN - potentially mineralizable nitrogen.

${ }^{2}$ Means for each treatment combination within rows with the same letter are not significantly different at $P<0.05$.

to our values, which is probably due to their mine soils being similar in age and constructed from brown and gray sandstone materials like our mine soils. Similar to our findings, Showalter et al. (2010) found that despite differences in soil chemical and physical properties, MBC and PMN in brown and gray mine soil materials were not significantly different. According to Schoenholtz et al. (1992), their unseeded sandstone mine soils were lacking in available $\mathrm{N}$ for $\mathrm{MBC}$ to be very high.

Rice et al. (1996) suggested that the ratio of MBC to total C (MBC: TC), as well as PMN to total N (PMN : TN), may provide an index of soil organic matter dynamics and soil quality. Some have suggested that mine soils have a large capacity for C storage (Shukla and Lal, 2005; Ussiri et al., 2006; Wick et al., 2009a, b), and these ratios should gradually decline with maturation and time to a stable ratio. In 
agricultural soils, MBC normally constitutes from 1 to $4 \%$ of the total C, while PMN comprises about 2 to $6 \%$ of total N (Anderson and Domsch, 1989; Jenkinson, 1988; Sparling, 1992). In mine soils, caution should be exercised in using MBC : $T C$ because $\mathrm{C}$ may exist as carbonate $\mathrm{C}$ and coal C. Over time, the carbonates and coal will weather and degrade, but initially high levels may be found in fresh mine soils. Therefore, in our study we used two ratios: MBC: TC and $\mathrm{MBC}$ to soil organic $\mathrm{C}$ (MBC: $\mathrm{OC}$ ). The MBC: OC ratio should be more accurate to correct the error associated with overestimating $\mathrm{C}$ contents with $\mathrm{C}$ fractions that are not utilized by microorganisms.

The ratio of MBC: TC in brown mine soils was significantly lower than the other three treatments ( 0.46 vs. an average of $0.93 \%$ for the others; Table 7). This result is seemingly contradictory because the brown mine soils with more total C (Table 6) should presumably have more MBC. However, coal $\mathrm{C}$ made up almost half of the total $\mathrm{C}$ in these mine soils (Table 6), thereby making almost half of the total $\mathrm{C}$ largely unavailable to microbial immobilization. To account for this factor, the ratio of MBC: OC should provide a better ratio to assess the percentage of utilizable $\mathrm{C}$ used for microbial biomass. Using this ratio, the brown treatment was still lowest at $1.08 \%$ with brown hydroseed, gray was next (1.82 and $2.02 \%$, respectively), and the gray hydroseed was significantly higher at $2.52 \%$. These values are on the low side but within those reported for agricultural soils (1 to $4 \%$; Anderson and Domsch, 1989).

The PMN : TN ratios of non-hydroseed mine soils in our study were 70 to $80 \%$ less than the PMN : TN ratio found in the hydroseed treatments (Table 7), indicating that much less of the $\mathrm{N}$ found in the soil was in the active fraction and was therefore not as available to plants and microbes (Stephens et al., 2001). Even though fertilizing with $\mathrm{N}-\mathrm{P}_{2} \mathrm{O}_{5}-\mathrm{K}_{2} \mathrm{O}$ by hydroseeding did not increase the total $\mathrm{N}$ (Table 6), fertilizing did increase the PMN and therefore significantly increased the PMN : TN ratio by 3 or 4 times. This higher ratio could have been one factor responsible for the much greater tree volume index recorded in hydroseed plots. A regression analysis by Showalter et al. (2010) showed that PMN was highly correlated with tree biomass and therefore the input of litter and nutrients was most likely the limiting factor of growth in mine soils. Perhaps limited $\mathrm{N}$ mineralization was responsible for low MBC in non-hydroseed mine soils of our study, which is further supported by the slightly higher MBC:TC ratio found in the hydroseed treatment. This higher ratio indicates that more carbon in the hydroseed treatment was in the active fraction (Insam and Domsch, 1988; Rice et al., 1996).

Hydroseed treatment had a significant effect on biochemical properties of the mine soils due to the earlier fertilization and seeding, which stimulated vegetation growth (Table 4). The resulting greater vegetation and litter provided available $\mathrm{C}$ and $\mathrm{N}$ for microflora and fauna that contributed to the higher MBC found in the hydroseed treatments. A higher PMN : TN indicated that more of the TN in hydroseed treat- ments was available to microbes. With this being the only difference between the treatments, we assume that herbaceous vegetation cover was an influential factor in $\mathrm{MBC}$ and PMN in these mine soils. Nitrogen-fixing legumes were introduced by hydroseed application, which could have influenced the $\mathrm{PMN}$ : TN ratio. The effect of legumes on $\mathrm{N}$ cycling is unclear since the total $\mathrm{N}$ content of the mine soils with and without hydroseed was not different and the PMN on hydroseed plots was significantly greater in both mine soils. The herbaceous cover contributed by seeded legumes was very low compared to the seeded grasses; therefore, it was assumed that the $\mathrm{N}$ differences were likely due to the earlier $\mathrm{N}$ fertilization.

Mummey et al. (2002) investigated biochemical properties and spatial relationships with plant communities and found that greater $\mathrm{MBC}$, soil organic matter and $\mathrm{N}$ depletions were concentrated at the base of plant stems. A similar trend could be occurring at the Birch River site where non-hydroseed plots had little initial soil organic $\mathrm{C}$ and $\mathrm{N}$ to produce plant growth. Our sampling methods did not take this into account, as soil samples were taken randomly at varying distances from tree bases. We may have diluted our samples by mixing samples near trees with samples further away from trees, thereby resulting in lower MBC and PMN. Had we sampled closer to tree bases, which were more abundant in hydroseed areas, we may have found our MBC and PMN values on nonhydroseed plots to be more similar to our hydroseed treatments.

Vegetation that rapidly decomposes and is recycled in mine soils appears to be beneficial for microbial activity. Herbaceous cover may promote a more homogenous soil environment, which could promote root expansion by trees and shrubs (Mummey et al., 2002). Other studies on reclamation and biochemical properties have demonstrated the positive impact of mulching and other organic matter additions on biological soil properties of reclaimed mine sites (Anderson et al., 2008; Machulla et al., 2005; Pallavicini et al., 2014; Showalter et al., 2010).

Our study was conducted 6 years after trees were planted and hydroseeding was performed, and as such provided a snapshot evaluation of reclamation progress at the site. Future studies at this site documenting changes of biochemical properties over time would better assess the nutrient cycling capabilities and restoration of soil quality at the site. In this manner, the success of reclamation practices and the return of ecosystem services could be evaluated. Other studies have examined these dynamic biochemical properties over time and demonstrated the development and evolution of microbial populations and diversity, which were used to indicate reclamation success on a site (Akala and Lal, 2001; Anderson et al., 2008; Chaudhuri et al., 2015; Insam and Domsch, 1988). According to a chronosequence study of reclaimed sites in West Virginia by Stephens et al. (2001), reclaimed mines saw a pulse in microbial activity and biomass in the first 10 years after reclamation, followed by a steady de- 
cline during the following years. This pulse was attributed to the rapid consumption of nutrients provided by fertilizers and the quick turnover of herbaceous vegetation and cycling of nutrients. Without additional inputs of nutrients, the plant community was slower to develop; lower amounts of organic materials were added to the soil, thereby resulting in reduced organic matter pools and nutrient cycling because few readily available nutrients were available for plant and microbial uptake. While PMN and MBC were higher in the hydroseed treatment in this study, it is possible that this site was only experiencing a temporary pulse in microbial activity, which will decline as it approaches 10 years of age.

\section{Summary and conclusions}

A diverse and active microbial population is essential for sustained primary productivity in ecosystems. Microbes are responsible for the majority of plant litter decomposition and facilitate nutrient cycling through immobilization and mineralization of soil organic compounds. Any drastic land disturbance dramatically alters and disrupts the integrity of the existing plant community, removes the soil resources, and destroys the soil microbial components of an ecosystem. In order to re-establish land capability, reclamation practices must re-establish a soil resource capable of supplying water and nutrients for the plant community and must provide the capacity to support a soil microbial community. With appropriate soil replacement, soil amendments and seeding, the process for developing an ecosystem on the site begins and gradually ecosystem function and stability can occur with time and maturation of the system. Reclamation practices that re-establish the soil, rapidly introduce organic matter, and promote soil microbial populations should be implemented. Brown mine soils were a better growth medium for trees and had higher total and organic $\mathrm{C}$ contents compared to gray mine soils. Hydroseeding at a rate of $35 \mathrm{~kg} \mathrm{ha}^{-1}$ with non-competitive tree compatible herbaceous vegetation and applying $336 \mathrm{~kg} \mathrm{ha}^{-1}$ of $10-20-10 \mathrm{~N}-\mathrm{P}_{2} \mathrm{O}_{5}-\mathrm{K}_{2} \mathrm{O}$ fertilizer had a significant effect on microbial biomass and activity. On brown mine soils, hydroseeding doubled the amount of MBC, and in both mine soils increased the MBC:OC and PMN : TN ratios. Our results indicate that hydroseeding with fertilizer and plant seeds is a useful and beneficial practice to promote plant establishment and to restore soil microbial populations.

Acknowledgements. The authors thank Keith O'Dell of Arch Coal for establishing the plots and for his financial support, and Lindsey Bishop and Greg Klinger for their assistance in the field and laboratory. Funding for this project came from Arch Coal, Birch River, and from funds appropriated under the Hatch Act.

Edited by: J. Vanderborght

\section{References}

Akala, V. and Lal, R.: Soil organic carbon pools and sequestration rates in reclaimed minesoils in Ohio, J. Environ. Qual., 30, 20982104, 2001.

Anderson, J. and Domsch, K.: Ratios of microbial biomass carbon to total carbon in arable soils, Soil Biol. Biochem., 21, 471-479, 1989.

Anderson, J., Ingram, L., and Stahl, P. D.: Influence of reclamation management practices on microbial biomass carbon and soil carbon accumulation in semiarid mined lands of Wyoming, App. Soil Ecol., 40, 387-397, 2008.

Angel, P., Barton, C., Warner, R., Agouridis, C., Taylor, T., and Hall, S.: Tree growth, natural regeneration, and hydrologic characteristics of three loose-graded surface mine spoil types in Kentucky, in: Proceedings, 25th Conference of the American Society of Mining and Reclamation, edited by: Barnhisel, R. I., 28-65, Lexington, USA, 2008.

Bendfeldt, E., Burger, J., and Daniels, W.: Quality of amended mine soils after sixteen years, Soil Sci. Soc. Am. J., 65, 1736-1744, 2001.

Brevik, E. C., Cerdà, A., Mataix-Solera, J., Pereg, L., Quinton, J. N., Six, J., and Van Oost, K.: The interdisciplinary nature of SOIL, SOIL, 1, 117-129, doi:10.5194/soil-1-117-2015, 2015.

Brookes, P. and Joergensen, R.: Microbial biomass measurements by Fumigation-Extraction, in: Biological methods for assessing soil quality, edited by: Bloem, J., Hopkins, D. W., and Benedetti, A., CABI Publishing, Cambridge, MA, USA, 77-83, 2006.

Canali, S. and Benedetti, A.: Soil nitrogen mineralization, in: Biological methods for assessing soil quality, edited by: Bloem, J., Hopkins, D. W., and Benedetti, A., CABI Publishing, Cambridge, MA, USA, 127-135, 2006.

Chatterjee, A., Lal, R., Shreshta, R., and Ussiri, D.: Soil carbon pools of reclaimed mine spoils under grass and forest land uses, Land Degrad. Dev., 20, 300-307, 2009.

Chaudhuri, S., McDonald, L., Skousen, J., and Pena-Yewtukhiw, E.: Soil organic carbon molecular properties: effects of time since reclamation in a minesoil chronosequence, Land Degrad. Dev., 26, 237-248, 2015.

Chodak, M., Pietrzykowski, M., and Niklinska, M.: Development of microbial properties in a chronosequence of sandy mine soils. App. Soil Ecol., 41, 259-268, 2009.

Delp, C.: Soil survey of Webster County, West Virginia, USDA, Natural Resources Conservation Service, Morgantown, WV, USA, available at: http://www.nrcs.usda.gov/Internet/FSE_ MANUSCRIPTS/west_virginia/WV101/0/wvwebster5_05.pdf (last access: 11 September 2015), 1998.

Elkins, N., Parker, L., Aldon, E., and Whitford, W.: Responses of soil biota to organic amendments in stripmine spoils in Northwestern New Mexico, J. Environ. Qual., 13, 215-219, 1984.

Emerson, P., Skousen, J., and Ziemkiewicz, P.: Survival and growth of hardwoods in brown vs. gray sandstone on a surface mine in West Virginia, J. Environ. Qual., 38, 1821-1829, 2009.

Fields-Johnson, C., Zipper, C., Burger, J., and Evans, D.: Forest restoration in steep slopes after coal surface mining in Appalachian USA: Soil grading and seeding effects, Forest Ecol. Manag., 270, 126-134, 2012.

Franklin, J., Zipper, C., Burger, J., Skousen, J., and Jacobs, D.: Influence of planted ground cover on forest establishment and growth 
on eastern US coal surface mines, New Forests, 43, 905-924, 2012.

Groninger, J., Skousen, J., Angel, P., Barton, C., Burger, J., and Zipper, C.: Mine reclamation practices to enhance forest development through natural succession, Forest Reclamation Advisory No. 5, July 2007, Appalachian Regional Reforestation Initiative, available at: http://arri.osmre.gov/ (last access: 11 September 2015), 2007.

Haering, K., Daniels, W., and Galbraith, J.: Appalachian mine soil morphology and properties: Effects of weathering and mining method, Soil Sci. Soc. Am. J., 68, 1315-1325, 2004.

Haney, R., Hossner, L., and Haney, E.: Soil microbial respiration as a tool to assess post mining reclamation, Int. J. Min. Reclam. Env., 22, 48-59, 2008.

Ingram, L., Schuman, G., Stahl, P., and Spackman, L.: Microbial respiration and organic carbon indicate nutrient cycling recovery in reclaimed soils, Soil Sci. Soc. Am. J., 69, 1737-1745, 2005.

Insam, H. and Domsch, K.: Relationship between soils organic carbon and microbial biomass on chronosequences of reclamation sites, Microb. Ecol., 15, 177-188, 1988.

Jenkinson, D.: Determination of microbial biomass carbon and nitrogen in soil, in: Advances in Nitrogen Cycling in Agricultural Ecosystems, edited by: Wilson, J. R., CAB Int., Wallingford, England, 368-386, 1988.

Lindemann, W., Lindsey, D., and Fresquez, P.: Amendment of mine spoil to increase the number and activity of microorganisms, Soil Sci. Soc. Am. J., 48, 574-578, 1984.

Littlefield, T., Barton, C., Arthur, M., and Coyne, M.: Factors controlling carbon distribution on reforested minelands and regenerating clearcuts in Appalachia, USA, Sci. Total Environ., 465, 240-247, 2013.

Machulla, G., Burns, J., and Scow, K.: Microbial properties of mine spoil materials in the initial stages of soil development, Soil Sci. Soc. Am. J., 69, 1069-1077, 2005.

McFee, W., Byrnes, W., and Stockton, J.: Characteristics of coal mine overburden important to plant growth, J. Environ. Qual., 10, 300-308, 1981.

Miller, J., Barton, C., Agourdis, C., Fogel, A., Dowdy, T., and Angel, P.: Evaluating soil genesis and reforestation success on a surface coal mine in Appalachia, Soil Sci. Soc. Am. J., 76, 950-960, 2010.

Mulvaney, R.: Nitrogen-inorganic forms, in: Methods of Soil Analysis, Part 3, edited by: Sparks, D. L., Page, A. L.,Helmke, P. A., Loeppert, R. H., Soltanpour, P. N., Tabatabai, M. A., Johnston, C. T., and Sumner, M. E., Chemical Methods, Chapter 4, Soil Sci. Soc. Am., Madison, WI, USA, 1146-1162, 1996.

Mummey, D., Stahl, P., and Buyer, J.: Soil microbiological properties 20 years after surface mine reclamation: spatial analysis of reclaimed and undisturbed sites, Soil Biol. Biochem., 34, 17171725, 2002.

Pallavicini., Y., Alday, J., and Martinez-Ruiz, C.: Factors affecting herbaceous richness and biomass accumulation patterns of reclaimed coal mines, Land Degrad. Dev., 26, 211-217, 2014.

$\mathrm{R}$ Development Core Team: R - A language and environment for statistical computing, reference index version 2.13.0, $\mathrm{R}$ Foundation for Statistical Computing, ISBN 3-90051-08-9, Vienna, Austria, available at: http://www.R-project.org, last access: 15 February 2013.
Rice, C., Moorman, T., and Beare, M.: Role of microbial biomass carbon and nitrogen in soil quality. Chapter 12, in: Methods for Assessing Soil Quality, edited by: Doran, J. W. and Jones, A. J., SSSA Spec. Publ. No. 49, Soil Sci. Soc. Am., Madison, WI, USA, 203-215, 1996.

Rodrigue, J. and Burger, J.: Forest soil productivity of mined land in the Midwestern and Eastern coalfield regions, Soil Sci. Soc. Am. J., 68, 833-844, 2004.

Schoenholtz, S., Burger, J., and Kreh, R.: Fertilizer and organic amendment effects on mine soil properties and revegetation success, Soil Sci. Soc. Am. J., 56, 1177-1184, 1992.

Showalter, J., Burger, J., and Zipper, C.: Hardwood seedling growth on different mine spoil types without and with topsoil amendment, J. Environ. Qual., 39, 483-491, 2010.

Shukla, M. and Lal, R.: Temporal changes in soil organic carbon concentration and stocks in reclaimed minesoils of southeastern Ohio, Soil Sci., 170, 1013-1021, 2005.

Skousen, J., Zipper, C., Burger, J., Barton, C., and Angel, P.: Selecting materials for mine soil construction when establishing forests on Appalachian mine sites. Forest Reclamation Advisory No. 8, July 2011, Appalachian Regional Reforestation Initiative, available at: http://arri.osmre.gov/ (last access: 11 September 2015), 2011.

Sparling, C.: Ratio of microbial biomass to soil organic carbon as a sensitive indicator of changes in soil organic matter, Aust. J. Soil Res., 30, 195-207, 1992.

Stephens, K., Sexstone, A., Sencindiver, J., Skousen, J., and Thomas, K.: Microbial indicators of minesoil quality in southern West Virginia, in: Proceedings of the 16th Annual Meeting on Land Reclamation - A Different Approach, vol. 1, American Society of Mining and Reclamation, Lexington, KY, USA,317325, 3-7 June 2001.

Stroo, H. and Jencks, E.: Enzyme activity and respiration in minesoils, Soil Sci. Soc. Am. J., 46, 548-553, 1982.

Thomas, C.: Evaluation of tree growth and chemical, physical and biochemical soil properties of two reclaimed surface mines in West Virginia, Master's Thesis, West Virginia University, Morgantown, WV, USA, 98 pp. 2012.

Ussiri, D. and Lal, R.: Method for determining coal carbon in the reclaimed minesoils contaminated with coal, Soil Sci. Soc. Am. J., 72, 231-237, 2008.

Ussiri, D., Lal, R., and Jacinthe, P.: Post-reclamation land use effects on properties and carbon sequestration in minesoils of southeastern Ohio, Soil Sci., 171, 261-271, 2006.

Waschkies, C. and Hüttl, R.: Microbial degradation of geogenic organic $\mathrm{C}$ and $\mathrm{N}$ in mine spoils, Plant Soil, 213, 221-230, 1999.

Whiting, D., Card, A., Wilson, C., and Reeder, J.: Saline soils, Colorado Master Gardener Program, Colorado State University Extension, available at: http://www.ext.colostate.edu/mg/ gardennotes/224.html (last access: 11 September 2015), 2010.

Wick, A., Ingram, L., and Stahl, P.: Aggregate and organic matter dynamics in reclaimed soils as indicated by stable carbon isotopes, Soil Biol. Biochem., 41, 201-209, 2009a.

Wick, A., Ingram, L., and Stahl, P.: Aggregate associated carbon and nitrogen in reclaimed sandy loam soils, Soil Sci. Soc. Am. J., 73, 1852-1860, 2009b.

Wilson-Kokes, L., Emerson, P., DeLong, C., Thomas, C., and Skousen, J.: Hardwood tree growth after eight years on brown and 
gray mine soils in West Virginia, J. Environ. Qual., 42, 13531362, 2013a.

Wilson-Kokes, L., Emerson, P., DeLong, C., Thomas, C., O’Dell, K., and Skousen, J.: Hardwood tree growth on amended mine soils in West Virginia, J. Environ. Qual., 42, 1363-1371, 2013 b.
Zipper, C., Burger, J., Skousen, J., Angel, P., Barton, C., Davis, V., and Franklin, J.: Restoring forests and associated ecosystem services on Appalachian coal surface mines, Environ. Manage., 47, 751-765, 2011.

Zipper, C., Burger, J., Barton, C., and Skousen, J.: Rebuilding soils for forest restoration on Appalachian mined lands, Soil Sci. Soc. Am. J., 77, 337-349, 2013. 